\title{
Pollen management and controlled pollination in Eucalyptus urophylla
}

\section{Manejo de polen y polinización controlada en Eucalyptus urophylla}

ORTEGA-RAMIREZ, Marynor Elena $\dagger^{*}$, MENDEZ-ARCOS, Jorge Luis, TORRES-LAMAS, Secundino and SANCHEZ-MENDEZ, Francisco Rafael

\author{
Universidad Autónoma de Chiapas. Technical support. CONACYT - CONAFOR -A3-S-130398 Project. \\ Universidad Juarez Autonoma de Tabasco. CONACYT-CONAFOR Project Collaborator.
}

ID $1^{\text {st }}$ Author: Marynor Elena, Ortega-Ramírez / ORC ID: 0000-0002-2551-4054, Researcher ID: S-4732-2018, CVU CONACYT ID: 446579. Technical Resp. CONACYT Project - CONAFOR A3-S-130398

ID $1^{\text {st }}$ Co-author: Jorge Luis, Mendez-Arcos / ORC ID: 0000-0002-9641-8836, CVU CONACYT ID: 1039455. Project

ID $2^{\text {nd }}$ Co-author: Secundino, Torres-Lamas / ORC ID: 0000-0002-1060-7776, CVU CONACYT ID: 639341

ID $3^{\text {rd }}$ Co-author: Francisco Rafael, Sanchez-Mendez / ORC ID: 0000-0003-3532-1667 CONACYT-CONAFOR Project Assistant

\begin{abstract}
The genus Eucalyptus has shown great potential for the establishment of commercial forest plantations, it is one of the most widely planted worldwide, it is planted in different regions of the planet, which indicates its ability to adapt to various environmental conditions. Eucalyptus urophylla is a species of this genus that adapts to tropical and subtropical regions, in suitable sites it can achieve high growth rates. It is one of the species with the most research in breeding programs in the world, mainly due to its capacity to hybridize naturally, since it generates populations with high genetic diversity, coupled with its ability to reproduce asexually. In Mexico, the breeding programs for Eucalyptus urophylla are in the initial phase, although plantations are already managed under clonal silviculture, controlled crossing are just beginning, so pollen management and crossing techniques are the most important activities in these programs. Since there is currently no information about the management of pollen for Eucalyptus urophylla in Mexico, the aim of this paper is to show a methodology based on the information documented in other parts of the world and the recent experience acquired in the collection and management of pollen, as well as the controlled pollination techniques recently employed in the breeding programs of Eucalyptus urophylla in southeastern Mexico.
\end{abstract}

Eucalyptus urophylla, Controlled pollination, Cloning

\begin{abstract}
Resumen
El género Eucalyptus ha demostrado un gran potencial para el establecimiento de plantaciones forestales comerciales, es de los géneros más plantados a nivel mundial, se cultiva en diferentes regiones del planeta, lo cual indica la capacidad que tiene para adaptarse a diversas condiciones ambientales. Eucalyptus urophylla es una especie de este género que se adapta muy bien a regiones tropicales y subtropicales, en sitios idóneos puede lograr altas tasas de crecimiento. Es una de las especies con mayor investigación en programas de mejoramiento genético en el mundo, debido, principalmente a la facilidad para hibridarse de forma natural; ya que genera poblaciones con alta diversidad genética, aunado a su capacidad de reproducirse asexualmente. En México, los programas de mejora genética de Eucalyptus urophylla se encuentran en fase inicial, aunque ya se manejan plantaciones bajo silvicultura clonal, recién se están empezando los programas de cruzamientos controlados, por lo que el manejo de polen y las técnicas de cruzamiento son de las actividades más importantes en estos programas. Debido a que actualmente no existe información respecto al correcto manejo de polen para Eucalyptus urophylla en México, el objetivo del presente trabajo es mostrar una metodología basada en la información documentada en otras partes del mundo y a la experiencia adquirida hasta el momento en la colecta y manejo de polen, así como las técnicas de polinización controlada empleadas recientemente en el mejoramiento genético de Eucalyptus urophylla en el sureste de México.
\end{abstract}

Eucalyptus urophylla, Polinización controlada, Clonación

Citation: ORTEGA-RAMIREZ, Marynor Elena, MENDEZ-ARCOS, Jorge Luis, TORRES-LAMAS, Secundino and SANCHEZ-MENDEZ, Francisco Rafael. Pollen management and controlled pollination in Eucalyptus urophylla. Journal of Natural and Agricultural Sciences. 2021. 8-22:1-7.

\footnotetext{
* Author Correspondence (Email: marynor.ortega@ gmail.com)

$\dagger$ Researcher contributing as first author.
} 


\section{Introduction}

Eucalyptus urophylla S.T. Blake is a commercially important fast-growing species in Mexico's forestry industry. Currently it is one of the main species most planted in our country due to the quality of its wood for various purposes.

The success of the plantations lies in the use of improved forest germplasm obtained from genetic improvement programs. At present, almost all of the Eucalyptus urophylla plantations in Mexico are established with rooted cuttings (clones) of trees selected in breeding trials and local plantations established from propagation material of seminal origin.

Through the use of clones, the genetic gains of the improvement programs have been maximized, the yield and some morphological traits (crown and stem) of the trees have been increased, which has allowed to have more homogeneous and larger plantations. productivity. Despite this, the establishment of monoclonal plantations brings about a drastic decrease in the genetic diversity of the system (Bonnin et al., 2020).

This decrease in genetic diversity eliminates the possibility of using the best genotype in each site (Bonnin et al., 2020), in addition, the use of the same genotype has a negative effect on production, since the presence of an event extreme climate, or the appearance of a pest or disease increases the risk of mortality of the trees (Larjavaara, 2008).

One way to improve the disadvantages caused by the use of pure clones is to perform controlled crosses between selected genotypes with outstanding characteristics. This technique has made it possible to improve adaptation to sites or the productive characteristics of the most commercially important species (Rojas, 2014).

Controlled pollination allows the characteristics of superior trees to be mixed. From the mixture, individuals with the traits transmitted by their parents are obtained. The main approach that has been given to this methodology is obtaining hybrids to improve the adaptive capacity of trees that present some operational disadvantage as a pure species.
The main characters that have been improved with hubriding are: productivity, wood quality, resistance to pests and diseases, and resistance to adverse climatic effects such as frosts or prolonged droughts (Medina et al., 2014).

The use of hybrid clones obtained through controlled crosses is very widespread. Of the genera with the greatest advance in the use of hybrid clones is Populus, $100 \%$ of the plantations are made with hybrid materials (Medina et al., 2014). Although the development has been more recent, in Pinus hybrids have also been obtained that are currently being used by some companies worldwide such as: the hybrids Pinus elliottii $\mathrm{x}$ Pinus caribaea var. Hondurensis, Pinus patula x Pinus tecunumanii and Pinus patula $\mathrm{x}$ Pinus oocarpa (Medina et al., 2014).

In Chile, through controlled pollination, the adaptation of Eucalyptus globulus to areas with adverse conditions has been improved through the generation of hybrids with other species resistant to frost (Eucalyptus nitens) and droughts (E. camaldulensis) (Rojas, 2014). Some particular cases such as Brazil, $100 \%$ of the plantation programs with Eucalyptus are sustained with the use of hybrid clones obtained in controlled crossing programs (Medina et al., 2014).

Although controlled pollination has been developed for some decades now, in Mexico, this methodology is new and is still beginning to be implemented in some species such as Eucalyptus urophylla.

According to the diagnosis made by CONAFOR \& AMEPLANFOR (2016), the projections indicate a demand for forest germplasm of Eucalyptus urophylla to plant around 3,000 ha during the next few years. Therefore, it is important to accelerate genetic improvement programs, which is possible if the reproductive biology of the species is known (Espejo et al., 1996). In our country, the purpose of implementing controlled pollination is to obtain highly productive genotypes of Eucalyptus urophylla, resistant to pests and diseases, and to improve the characteristics of the wood for alternative uses to that which is currently being given in the production of chips for the manufacture of medium density fibreboard (MDF).

ORTEGA-RAMIREZ, Marynor Elena, MENDEZ-ARCOS, Jorge Luis, TORRES-LAMAS, Secundino and SANCHEZMENDEZ, Francisco Rafael. Pollen management and controlled pollination in Eucalyptus urophylla. Journal of Natural and Agricultural Sciences. 2021 
Since there is no detailed information in this regard, the following work aims to describe a methodology for the collection and management of pollen, as well as to describe the controlled pollination techniques that are currently being implemented in Eucalyptus urophylla in southeastern Mexico. The methodology that is described is based on the experience recently obtained in Mexico carrying out controlled crosses in Eucalyptus urophylla, however, it was developed taking as a reference the controlled pollination techniques documented in other countries, for other species of the genus Eucalyptus.

\section{Importance of controlled crosses}

The importance of implementing controlled crosses is to obtain genetic material for the establishment of progeny trials, which will serve as a basis for obtaining advanced generations that provide valuable information regarding the genetic quality of the parents currently selected in plantations and breeding trials. The second is the production of material of high genetic value of Eucalyptus urophylla as a pure species and its hybrids to guarantee forest production in the medium and long term, promoting sustainable development through the establishment of highly productive forest plantations.

\section{Pollen management}

Seed production through controlled pollination may have losses if proper pollen management is not done, especially in Eucalyptus that presents floral asynchrony (Espejo et al., 1996). Correct handling will be essential to guarantee the success of pollination in controlled crossing programs.

\section{Pollen collection}

The first stage in collecting pollen is the selection of genetically superior trees. Currently almost all of the Eucalyptus urophylla trees in Mexico are selected in genetic improvement trials (provenances, progeny, clonal) and in a lower percentage of local plantations with materials from seminal origin. The trees that are chosen are those that express the characteristics of interest for timber production.
In any genetic improvement program, selection is one of the most important stages where you must be very careful since the selected trees will form the base population that will provide the genes for the controlled pollination program.

Trees from breeding trials are selected based on a genetic ranking, after statistically analyzing each of the trials, comparing the development and quality, in terms of volume and shape, of each of the trees (Rojas et al. , 2007). Selection in operational plantations is carried out with the method of comparison between the candidate tree and its five best neighbors, this method is generally known as mass selection (Rojas et al., 2007), since the trees are selected only by their phenotype regardless of information about the performance of their ancestors, progeny or other selected individuals. It is the recommended method when the relationship of the trees is unknown (Rojas et al., 2007). For timber production, the trees have to be dominant trees, with a straight cylindrical stem, showing resistance to pests and diseases, with a leafy and round crown, with a diameter and height above the population average.

To collect pollen, the flowering of the trees is monitored, although in Mexico, there is no detailed study of the phenology of Eucalyptus urophylla, it has been seen that flowering begins in the month of May (personal observation). The inflorescence is an umbel organized in an odd number of flower buds, generally five to seven, rarely three buds per umbel. The bud is made up of a receptacle covered by the operculum, the operculum covers the pistil and the stamens of a hermaphroditic flower that detaches when mature to release pollen (van Wyk, 1977).

To collect pollen, the buttons have to be in the pre-synthesis stage (Espejo et al., 1996), almost at the moment the operculum begins to detach, a clearly identifiable visual sign is the yellow coloration of the flower button, this stage it is reached between the month of August and September (personal observation). There are two ways to collect pollen. The first is by cutting the branches directly from the tree, for this, the trees are climbed to where the branches with the mature flower buds are. Specialized equipment is used to climb, the essential accessories are: helmet, gloves, climbing spurs, harness, safety rope and descent rope. 


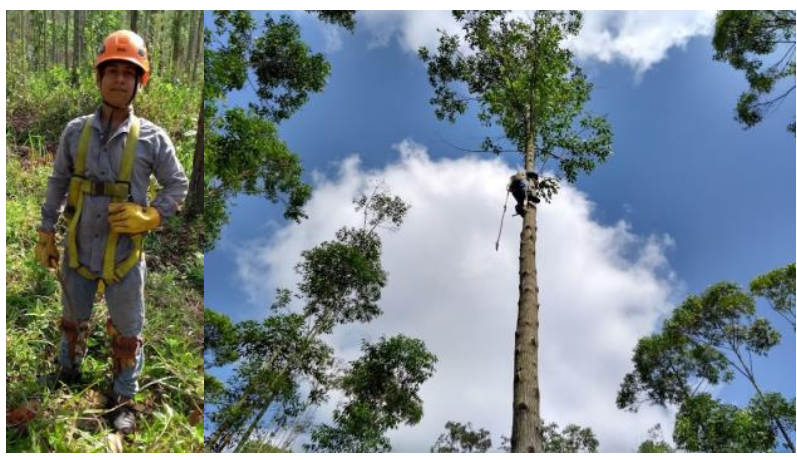

Figure 1 Climbing equipment for pollen collection in selected trees of Eucalyptus urophylla

When the branches are cut, the leaves are cut $50 \%$ in order to reduce evapotranspiration (Espejo et al., 1996). To cut the branch it is necessary to guarantee that more than $60 \%$ of the buttons are in the pre-synthesis stage. Flowers are isolated before anthesis because insect visits contaminate and also reduce the amount of available pollen (van Wyk, 1977). The branches are kept in polyethylene bags and placed in a cooler with enough ice, fully identified with indelible ink.

\section{Pollen management in the laboratory}

In the laboratory the branches are placed in buckets with water, the base of the branch must be in direct contact with the water so that the material maintains its vigor and continues the normal flowering process. After a few hours, when the operculum begins to detach, it is cut with a scalpel or nail scissors to detach it completely.

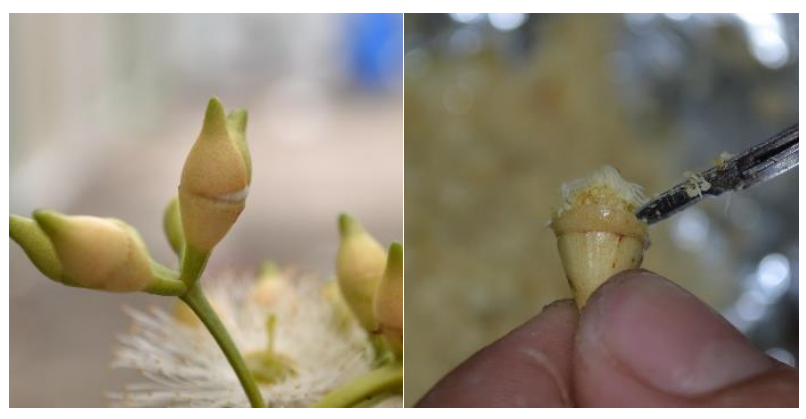

Figure 2 Detachment of the operculum and cutting of the stamens with the anthers

Another way to collect pollen is to emasculate the flowers on the ground (Espejo et $a l ., 1996)$. This is possible if the genotype is very valuable and does not have a sufficient number of buds, to avoid waste and collect buds in the maturing process, this procedure can be carried out.
The open buds are emasculated in the field and the stamens are collected with the anthers, they are placed in Petri dishes that are later transported in coolers to the laboratory. In Mexico, this process is less used due to the complexity of carrying it out. The top trees that are selected are adult trees that have to be climbed in order to collect pollen. Emasculating the flower in the field in these trees is an impractical and dangerous procedure to carry out in the heights. However, in breeding trials it has been seen that some genotypes produce some buds after the first year (personal observation), when the trees are low in height, under these circumstances it is possible to emasculate in the field to take advantage of the maximum amount of pollen.

\section{Pollen drying}

The extracted anthers are placed in a Petri dish with the base covered with aluminum foil. Subsequently, the Petri dish is placed in a desiccator with a silica gel at the base to extract the moisture. The estimated time for the moisture to be completely extracted from the anthers is around $48 \mathrm{~h}$ (personal observation). All pollen information is written on a label for identification; the number of the tree, family or clone, date of collection and date on which it was put to dry.

\section{Pollen storage}

Correct pollen management will have a positive impact on the result of controlled crosses, these results will guarantee the efficiency and costs of genetic improvement programs (Medina et al., 2014). Storage is an important stage of pollen management, the correct use of materials and temperature are crucial to maintain viability.

Once the moisture has been removed from the anthers, they are passed through sieves with different mesh openings to extract the pollen grain. The mesh apertures used in Eucalyptus urophylla are 250, 212 and $180 \mu \mathrm{m}$. With the opening of $250 \mu \mathrm{m}$, the remains of stamens that remain in the sample are eliminated, then the pollen is passed through the $212 \mu \mathrm{m}$ sieve and at the end through the $180 \mu \mathrm{m}$, with this last sieve the pollen grain is obtained completely clean. 
The sieves must be used by genetype, each time the pollen is changed, the sieves must be washed carefully with normal water and distilled water to avoid contamination between the pollen of the different genotypes. The collected pollen is stored fully identified in gel capsules or any other vial, they are stored by family or clone as appropriate. The vials are placed in a refrigerator at a temperature of 2 to 4 ${ }^{\circ} \mathrm{C}$ (Dickinson et al., 2010).

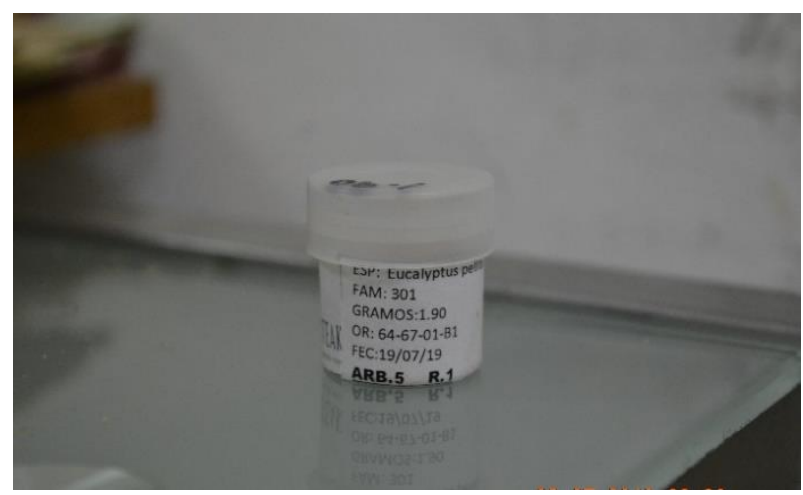

Figure 3 Pollen storage in fully identified plastic vial

\section{Controlled pollination}

Controlled pollination is a way to increase the genetic variability of the population, especially in genetic improvement programs that have a narrow genetic base (Rezende et al., 2014). In the long term it is a way of maintaining an elite unrelated population for the benefit of the genetic improvement program. When the genetic base is narrow, a viable option is to recombine the best existing commercial clones (Rezende et al., 2014).

One of the great challenges faced by breeders is to get the parent trees to flower as soon as possible and in a uniform way to be able to carry out controlled crosses. In this sense, there has been a lot of progress in recent decades, the times from 4-8 years that it normally takes for the genus Eucalyptus to flower have been reduced to 2-4 years through different techniques that involve the use of grafts, water management. and nutrition, and hormonal treatment (Rezende et al., 2014). In Eucalyptus urophylla in Mexico, the method used is the use of grafts of cuttings from adult trees treated with paclobutrazol to stimulate flowering.

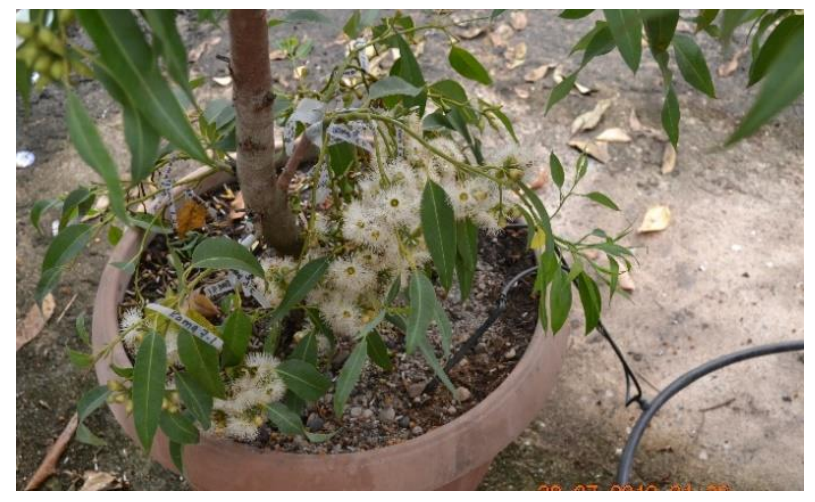

Figure 4 Flowering of grafted Eucalyptus urophylla

Throughout the process of genetic improvement in Eucalyptus, different techniques have been developed to carry out controlled crosses. The traditional method (van Wyk, 1977) was the first to be used. The method consists of removing the stamens with the anthers (emasculation) once the operculum has detached, then the emasculated buds are covered with a cloth bag to prevent the entry of unwanted pollen and wait for the receptivity of the stigma, this process it takes three to four days after emasculating. When the stigma is receptive (increased thickness), the pollen is placed and covered with the bag, after a period of two to four weeks the bag is removed, this period is considered sufficient for the pollen to germinate and fertilize the ovule for the process of seed formation to take place (van Wyk, 1977). However, given that this technique requires a lot of effort and time, in addition to the fact that there is a lot of manipulation of the flower bud, which ultimately impacts seed production, the single visit pollination technique (OSP, for its acronym in English) as an alternative to improve the production of Eucalyptus globulus in Chile (Harbard et al., 2000). With this technique it is possible to emasculate and pollinate at the same time. It arises from the theory that it is not necessary to wait for the normal process of receptivity of the stigma, and that the bag is not the only object to avoid contamination by foreign pollen (Harbard et al., 2000). The technique consists of emasculating immediately when the operculum has detached, a cut is made at the tip of the stigma of 1 to $2 \mathrm{~mm}$, the pollen is placed and covered with a plastic tube to avoid the entry of pollen other than the desired one. All at the same time. The use of this technique allowed to drastically reduce costs in the Eucalyptus globulus controlled crossing programs in Chile (Rojas, 2014), since the entire operation is carried out in a single visit. 
Although in Mexico, there is no history of the use of this technique in Eucalyptus urophylla, the preliminary results obtained in recent trials are promising and suggest that it is possible to obtain improved seed in controlled crossing programs, hybrids of Eucalyptus pellita $\mathrm{x}$ Eucalyptus urophylla have been obtained in trees grafted under greenhouse conditions in Huimanguillo, Tabasco. More recent trials (still under evaluation) show promise in obtaining hybrids of Eucalyptus urophylla x Eucalyptus grandis with the OSP technique.

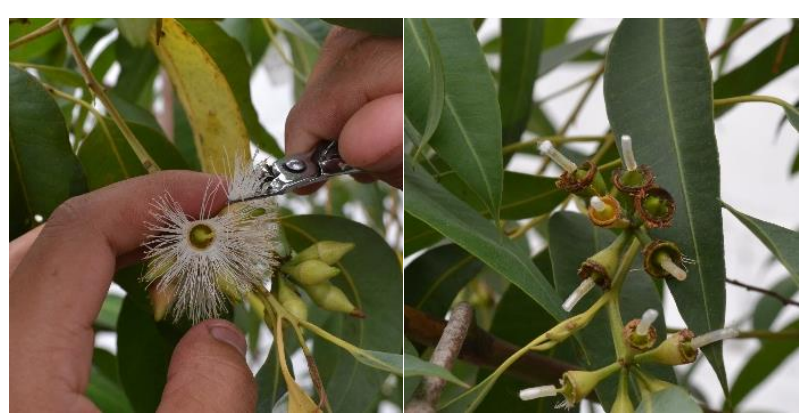

Figure 5 Emasculation and pollination of Eucalyptus urophylla

Although the OSP technique originated as a way to improve the controlled pollination of Eucalyptus globulus, the results have allowed it to be used with other species such as Eucalyptus grandis (Harbard et al., 2000), the technique has also been extended to the generation of hybrids of Corymbia (Dickinson et al., 2010). However, in experiments with small-flowered species such as Eucalyptus nitens, the technique has not been successful due to the low number of seeds that have been obtained (Williams et al., 1999).

To solve this problem, the artificially induced protogyny (AIP) technique emerged (Assis et al., 2005). According to Assis et al., (2005) the low seed production with the OSP technique in Eucalyptus with small flowers is due to the fact that the flower receives damage at the time of emasculation, because the base from where the seeds originate has to be cut stamens. If you do not have the appropriate tool or the management is not appropriate, you run the risk of having a low seed production. With AIP the damage to the flower is less, since only the tip of the stigma is cut and it is not necessary to emasculate. This technique yielded favorable results in Brazil in the controlled pollination of Eucalyptus urophylla and the hybrid Eucalyptus grandis $\mathrm{x}$ Eucalyptus urophylla when they were used as mothers (Assis et al., 2005).
In Mexico, trials with the AIP technique have begun in Eucalyptus urophylla. The results look promising, however, more research is needed.

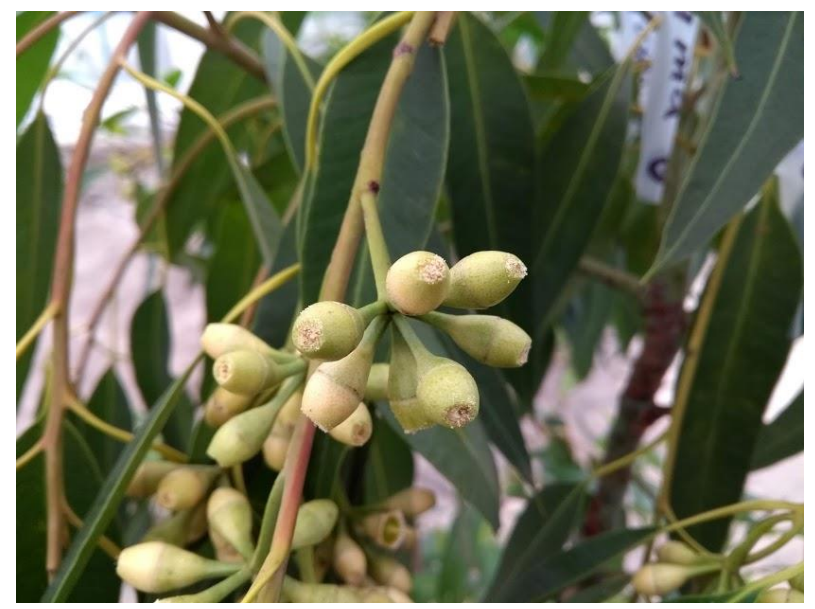

Figure 6 AIP technique in Eucalyptus urophylla

\section{Acknowledgments}

To the research project "Early evaluation of progeny and clonal tests of Eucalyptus urophylla used in commercial forest plantations of the company Forestaciones Operativas de México S.A. de C.V. in the state of Tabasco" from the Sectorial Fund for Forestry Research, Development and Technological Innovation (code: A3-S-130398), for the financing granted; and the company Forestaciones Operativas de Mexico S.A de C.V. for the facilities granted for the development of work.

\section{Conclusions}

Since there is no research in this regard in Mexico, the methodology described in this work is the result of the experience recently achieved in controlled crossbreeding programs with Eucalyptus urophylla in Mexico. However, it was developed based on other documented controlled crossing programs for other Eucalyptus species around the world. It is recommended to continue carrying out research on the subject, since it is still possible to make adjustments for a better adaptation of the methodology to the conditions of Eucalyptus urophylla in Mexico. 


\section{References}

Assis, T., Warburton, P., \& Harwood, C. (2005). Artificially induced protogyny: an advance in the controlled pollination of Eucalyptus. Australian Forestry, 68(1), 27-33. https://doi.org/10.1080/00049158.2005.106762 23

Bonnin, S. M., Faustino, L. I., Alvarez, J. A., \& Graciano, C. (2020). ¿La combinación de clones posee alguna ventaja sobre los sistemas monoclonales? Posibles alternativas silviculturales para las Salicáceas, a partir de la revisión de experiencias previas. Revista de La Facultad de Agronomía, 119(2), 1-11. https://doi.org/10.24215/16699513e051

Comisión Nacional Forestal (CONAFOR), \& Asociación Mexicana de Plantadores Forestales A.C. (AMEPLANFOR). (2016). Situación actual del germoplasma utilizado en los programas de plantaciones forestales comerciales en el sureste de México.

Dickinson, G. R., Wallace, H. M., \& Lee, D. J. (2010). Controlled pollination methods for creating Corymbia hybrids. Silvae Genetica, 59(5), 233-241. https://doi.org/10.1515/sg2010-0028

Espejo, J., Ipinza, R., \& Potts, B. M. (1996). Manual de cruzamientos controlados para Eucalyptus nitens ( Deane et Maiden ) Maiden y Eucalyptus globulus ( Labill ). Cooperativa de Mejoramiento Genético.

Harbard, J. L., Griffin, A. R., Espejo, J. E., Centrurion, C., \& Russel, J. (2000). “One stop pollination" a new technology developed by Shell Forestry technology unit. In H. S. Dungey, M. J. Dieters, \& D. G. Nikles (Eds.), Proceedings of QFRI/CRC-SPF symposium: hybrid breeding and genetics of forest trees (pp. 430-434). Department of Primary Industries.

Larjavaara, M. (2008). A review on benefits and disadvantages of tree diversity. The Open Forest Science Journal, 1(1), 24-26. https://doi.org/10.2174/1874398600801010024
Medina, A., Emhart, V., Navarrete, R., Rothen, B., Labra, M., \& Velilla, E. (2014). Antecedentes de desarrollo y potencial productivo de variedades híbridas entre Eucalyptus nitens y Eucalyptus globulus en Chile. La experiencia CMPC. In R. Ipinza, S. Barros, B. Gutiérrez, \& N. Borralho (Eds.), Mejoramiento genético de eucaliptos en Chile ( $1^{a}$ Edición, pp. 251-264). Instituto Forestal.

Rezende, G. D. S. P., de Resende, M. D. V., \& de Assis, T. F. (2014). Eucalyptus breeding for clonal forestry. In T. Fenning (Ed.), Challenges and Opportunities for the World's Forests in the 21st Century (pp. 393-424). Springer, Dordrecht. https://doi.org/10.1007/978-94-0077076-8_16

Rojas, P. (2014). Biología reproductiva e hibridación de Eucalyptus globulus. In R. Ipinza, S. Barros, B. Gutiérrez, \& N. Borralho (Eds.), Mejoramiento genético de eucaliptos en Chile (1a Edición, pp. 203-212). Instituto Forestal.

Rojas, P., Molina, M. P., \& Perret, S. (2007). Técnicas de hibridación y clonación de Eucalyptus de zonas semiáridas.

van Wyk, G. (1977). Pollen handling, controlled pollination and grafting of Eucalyptus grandis. South African Forestry Journal, 101(1), 47-53. https://doi.org/10.1080/00382167.1977.962945 5

Williams, D. R., Potts, B. M., \& Black, P. G. (1999). Testing single visit pollination procedures for Eucalyptus globulus and $E$. Nitens. Australian Forestry, 62(4), 346-352. https://doi.org/10.1080/00049158.1999.106748 02 